\title{
Implementation of Queue Model for Measuring the Effectiveness of Suzuki Car Maintenance
}

\author{
Suriyanti Andi Mangkona \\ Associate Professor of Management Science \\ Muslim University of Indonesia, Indonesia \\ Imaduddin Murdifin \\ Assistant Professor of Management Science \\ Muslim University of Indonesia, Indonesia
}

Received: May 11, 2017

Accepted: June 2, 2017

Published: June 10, 2017

doi:10.5296/wjbm.v3i1.11320

URL: http://dx.doi.org/10.5296/wjbm.v3i1.11320

\begin{abstract}
Waiting on the queue system is something commonly experienced in life daily. However, actual waiting in queue system may cause discomfort for the individual and an economic cost for the company. PT. XYZ is a company providing facility Suzuki car maintenance in Makassar. The study was conducted to address the problems faced by PT. XYZ, namely: (a) Is the service available capacity is still inadequate, and (b) Does the customer need not wait a long time to receive a service. This problem was analyzed using queue theory, PT. XYZ has not been forced to increase its operating capacity, for example, be 5 Team Mechanics. The conclusion drawn on the basis, which the car does not need more time to waiting, be served. The service time is relatively short. The use of time in service activity have a fairly large proportion (98.54\%) and only 1: $46 \%$ of the time spent by the customer's waiting car maintenance services. The number of cars lined up waiting for their turn in the service (Lq) and the number of cars in the system, the queue to serve plus being served (Ls) is relatively small. Likewise Old cars lined up waiting service (Wq) and Old cars are in the system, queue time plus time served (Ws). The results showed that customers can be served satisfactorily at PT. XYZ.
\end{abstract}

Keywords: Suzuki car, Queue theory, Waiting time, Time to obtain the Service 


\section{Introduction}

The automotive industry in Japan will be applying the concept of servitization to enhance the ability to compete in global automotive market (Jacobs \& Chase, 2011). Servitization is a concept that integrates the main product manufacturing activity with the production of spare parts and vehicle service facilities required after a product the car arrived in the hands of consumers. Through the integrated concept of consumers find it easy to maintain the car was wearing the official garage and get the genuine parts. The Concept of servitization is one competitive advantage for Japan's automobile production to another country. The users of Suzuki car in Makassar and surrounding areas in need of genuine parts and Suzuki authorized repair shop to maintain and repair the car has. The presence of PT. XYZ in Makassar aims to address customer needs in question. In addition to an agent of the seller Suzuki, the company also has a workshop and shop units Suzuki genuine parts.

In this research activity is focused on the maintenance of the Suzuki cars. A car maintenance activity at authorized workshops actually consists of three stages, namely the stages of car maintenance, spare parts retrieval on unit parts stores and quality control. Maintenance of vehicles that arrive at the facility servicing carried out by the technical team. From the inspection of vehicles will be known that need to be spare parts replaced. Purpose equipment (spare parts) was written by Chief Mechanic in a memorandum of maintenance, and then submitted in unit parts shop.

Unit parts store will deliver spare parts in want consumers to record the name of spare parts, spare parts required quantity and price of spare parts as well as the number of police cars are serviced. After completion of the maintenance of the car by a team of mechanics, the car was taken to a place of testing (quality control station) to assess the work of a team of mechanics. If the car has met the conditions set out quality indicators, then the car was taken to the parking lot to the next handed over to the vehicle owner. However, analysis of the effectiveness of car maintenance services at PT. XYZ only focused on maintenance activities. Activities service and fulfillment of quality control ignored (not included in this analysis). Equipment used in the data analysis of the effectiveness of the maintenance of this car in where research is queue theory. Weekdays are used in a week is five days, i.e. Monday to Friday, excluding legal holidays set by the government. Working hours are 8 hours per day, from 08.00 until 16.00 while a break at 12:00 to 13:00, except for Friday at 11.30 - 13.30, and is therefore effective working hours per week is 34 hours (40 hours - 6 hours).

\section{Literature Review}

\subsection{Waiting Line Theory}

Waiting line theory also commonly called queuing theory. Theory queuing starts from the research work of a Danish engineer named AK Erlang. In 1909 Erlang conducted experiments on fluctuating demand in traffic long-distance call. Eight years later, Erlang published a report discussing delays in some connection requests and must wait his turn, (Chowdhury, 2013) study was later named the theory of the queue. The study of queues offer section with quantifying the phenomenon of waiting in lines representatives using measures of performance, 
such as average queue length, average waiting time in the queue, and average facility utilization (Taha, 2003, p. 579). The model line is useful to measure the effectiveness of the system as quickly and broadly with several indicators of essential services, i.e. estimates of: (a) How many customers are lining up waiting for service in a particular time, (b) How many customers are in the system, namely that being served and was in line waiting service, (c) How long will customers have to wait in line, before it was his turn to receive services, (d) How long the customer should be in the system, that is the time to receive the service and the time to wait in line before receive services, (e) How large is the system utilization of services, and (f) How large is the opportunity of the service system for the unemployed (Murdifin Haming et al., 2017).

There are three basic components that are in a queue system, namely: (a) the source of the population, (b) line system, and (c) the capacity of a service facility. The population in this case is a source of entities that came for services, such as: a customer at the counter service, a car at a fueling station, aircraft will landing or take-off at an airport, and the patients who come for treatment in a hospital. In this population-related characteristics of an entity, such as the pattern of arrival, whether scheduled or come randomly. The characteristics of the population are not limited to (infinite) or limited (finite) as well as the behavior of the entities in line. The behavior of these entities can be: (a) wait in line waiting for their turn, (b) impatient and leave the queue if it felt it was a long queue, and (c) wearing the jockey, ask a friend to line up and let me know if the turn has come. The overall behavior may affect the effectiveness of the service.

\subsection{Queue Structure}

General form the structure of line differentiated into six types, namely: (a) Single Channel, Single Phase Model (SC-SP), (b) Multi-Channel, Single Phase Model (MC-SP), (c) Single Channel, Multi phase Model (SC-MP), (d) Multi-Channel, Multi-phase Model (MC-MP), (e) Mixed phase, single to multiphase, and (f) Mixed with alternative phase (Murdifin Haming et al., 2017). From this study, this can be analyzed with the queue theory only on the structure of a single phase. Solving cases are usually solved with a multi-phase simulation method. Thus, the commonly wear line models are the type of Single Channel, Single Phase Model (SC-SP) and Multi Channel, Single Phase Model (MC-SP). Some experts define a form line structures as proposed Heizer (2017, p. 792) are shown in the following the table. 
Table 1. Queue structure

\begin{tabular}{|c|c|c|c|c|c|}
\hline Model & Technical Name & Example & $\begin{array}{c}\text { Number of } \\
\text { Channel }\end{array}$ & $\begin{array}{c}\text { Number of } \\
\text { Phases }\end{array}$ & $\begin{array}{c}\text { Service time } \\
\text { pattern }\end{array}$ \\
\hline A & $\begin{array}{c}\text { Single server system, } \\
\text { M/M/1 }\end{array}$ & $\begin{array}{c}\text { Information counter at } \\
\text { Department Store }\end{array}$ & Single & Single & Negative Exp. \\
\hline B & Multiple server, M/M/S & Airline ticket counter & Multi & Single & Negative Exp. \\
\hline C & Constant service, M/D/1 & Automated car wash & Single & Single & Constant \\
\hline D & $\begin{array}{c}\text { Finite population, } \\
\text { M/M/1 with finite source }\end{array}$ & $\begin{array}{c}\text { Shop with only a dozen } \\
\text { machines that might } \\
\text { break }\end{array}$ & Single & Single & Negative Exp. \\
\hline
\end{tabular}

Annotation: Arrival Patterns =Poisson, Population size = Unlimited, Queuing Disciplines: FIFO.

Anchored by the structure of the queue at the PT. XYZ whose shape is a Multi-Channel, Single Phase Model (MC-SP) is the same as Model B in Table 1 that customers are served by more than one team of mechanics, exactly as many as four of the team mechanics, stages of service after simplified only one. Before simplifying, there are at least two phases of service. The first stage is the maintenance of the vehicle and the second stage is quality control. All vehicles that have been serviced by a team of mechanics company in advance should be checked by a quality control officer to ascertain whether the work of the team mechanics have appropriate maintenance of quality standards set by the company.

\subsection{Component of Queue Model}

Queue is not an event that is alien, almost every day we are often involved in the event queue, such as when we want to fill up at the pump, saving money or take money at a bank, and at the time of visits to the hospital for treatment as well as the time comes to the garage for servicing vehicles (cars). In general, very little chance to directly serve. In general, consumers have to queue a while before it was time to be served. Source customer arrival declare at least four (Sharma, 2008; in Oyatoye et al., 2011), namely: (a) calling population (or input source), (b) queue process, (c) queue discipline, and (d) service process (or mechanism). Source customer arrival might finite or infinite. For this study, the source of the arrival of customers belonging to infinity, because comes from sources that are random and from outside the system. Vehicles that arrive requested service is not necessarily his home; his car is an important brand Suzuki. Line process rooted in the pattern of the car to the arrival of a service facility. The pattern of arrivals is random. At any given time a car came for the service one by one. At other times, the cars that come so suddenly exceed the capacity of the company, while at other times very less even none.

Based on such a state, then at a certain time, the car likely directly served and do not need to queue. But in other situations, because of the number of automobiles arrived, and then some of these cars have to queue before a turn of service. Service practices applied by the company is the car that arrived first, will be first served (applying rule: First Come, First Service, FC-FS), or FIFO (First In, First Out) as indicated in Table 1. The number of people lining and the length 
of the queue, depending on the number of cars arriving for a given service, this is the event that will be the object of this study.

\section{Research Methods}

Data collected through document study car maintenance services during the exploration of the Year 2015 by the size of the working time (month). The study documents used for detailing cars arrived asking for service, and who have completed service on working time / month. Data analysis was performed using Queue theory. There are several important variables related to the implementation of the Queue theory in question, namely:

a. Cars arrival rate in a given time to the service facility $(\Lambda)$.

b. Cars that can be served in the same time frame $(\mu)$.

c. The number of service channels, in this case the number of mechanics (M).

Model line feasible if it met the following requirements: $\mu \mathrm{M}>\Lambda$. The intent of this requirement is that the number of cars that can be served by the system, in this case by PT. XYZ per unit of time $(\mu \mathrm{M})$ must be greater than the cars arriving requested service $(\Lambda)$. Although the ability to serve more than a car coming, but for a car that arrived to be served, time of arrival is random, then the likelihood of the line has a great probability. In this study, the measurement will be carried out over a few things, namely;

a. The probability of the system (in the service) in a busy state, $\rho=K / \mu \mathrm{M}$

b. Probability system (facility services) to be empty, $P_{o}=1-\rho$

c. Number of cars lined up waiting for their turn in the service, Lq

$$
L_{q}=\frac{\lambda \mu(\lambda / \mu)^{M}}{(M-1) !(M \mu-\lambda)^{2}} x P_{0} \mathrm{P}_{0}=\frac{1}{\left[\sum_{\mathrm{n}=0}^{\mathrm{M}-1} \frac{1}{\mathrm{n} !}\left(\frac{\lambda}{\mu}\right)^{\mathrm{n}}\right]+\frac{1}{\mathrm{M} !}\left(\frac{\lambda}{\mu}\right)^{\mathrm{M}} \frac{\mathrm{M} \mu}{\mathrm{M} \mu-\lambda}}
$$

d. Number of cars in the system, the queue waiting for their turn Serviced plus being served, $\mathrm{Ls}=\mathrm{Lq}+\rho$

e. Old cars lined up waiting to serve, $\mathrm{Wq}=\mathrm{Lq} / K=\mathrm{Ws}-\frac{1}{\mu}$

f. Older cars are in the system, the time line up plus time served, Ws

$$
W_{s}=\frac{\mu(\lambda / \mu)^{M}}{(M-1) !(M \mu-\lambda)^{2}} P_{0}+\frac{1}{\mu} \text { Or Ws }=\mathrm{Ls} / \Lambda
$$

g. Queue cost.

Queue Model M / M / S can be applied in circumstances that meet the following assumptions: 
a. Service facility has two or more servers or services that are identical channels.

b. The arrivals of the object (car) to a service facility requesting the service are random and follow the pattern of the Poisson probability distribution. The average arrival of items per unitary time $=\Lambda$.

c. Activity Award for service to follow the negative exponential distribution and average capacity per unitary time services expressed by $\mu$. The average capacity of the service is identical for each server or service channel.

d. FCFS queue discipline to follow the rules

e. Will be queued car that arrive at one of the service channels (servers) that exist, and advanced to the maintenance system in any of the first channel is empty.

f. Objects (cars) that arrived will patiently wait their turn, and nothing is going to leave the queue.

\section{Research Data Analysis}

Data were collected for 25 working days, starting on January 6, 2015 until February 7, 2015. The data collected is the data the cars arriving at a service facility to request maintenance services. Arrivals are specified by cars coming into each channel (mechanics) are there. There are four channels or servers that provide PT. XYZ. The car served overall recorded in according to the data submitted car before and after service.

Cars that have completed the service does not directly handed over to the vehicle owner. But the car submitted to the quality control unit to check the performance of maintenance that has been done by the team mechanics. If the result of quality inspection maintenance services that have been performed by a team of mechanical compliance with the standards set by Suzuki, the car in question can be left to the owner. Fixed checking if the results of the quality control unit consist of one or several standard items have not been fulfilled, the car in question is returned to the team of mechanics to do repair under quality control unit the records. This was done to enhance the quality of a service provided as well as to increase the satisfaction of the Suzuki car owners. 
Table 2. Data of arrival and car service in PT. XYZ

\begin{tabular}{|c|c|c|c|c|c|c|c|c|c|}
\hline \multirow[t]{2}{*}{ No } & \multirow[t]{2}{*}{ Day / Date. Arrival } & \multicolumn{4}{|c|}{$\begin{array}{l}\text { Cars arrive at the } \\
\text { Mechanical team }\end{array}$} & \multirow{2}{*}{$\begin{array}{l}\text { Number of } \\
\text { cars arrive }\end{array}$} & \multirow{2}{*}{$\begin{array}{c}\text { Serviced } \\
\text { cars }\end{array}$} & \multirow{2}{*}{$\begin{array}{l}\text { effective } \\
\text { working } \\
\text { hours*) }\end{array}$} & \multirow{2}{*}{$\begin{array}{c}\text { Average } \\
\text { arrivals per } \\
\text { hour }\end{array}$} \\
\hline & & 1 & 2 & 3 & 4 & & & & \\
\hline 1 & Tuesday, January 6, 2015 & 15 & 11 & 10 & 14 & 50 & 45 & 7 & 7,142857 \\
\hline 2 & Wednesday, January 7, 2015 & 12 & 8 & 14 & 10 & 44 & 46 & 7 & 6,285714 \\
\hline 3 & Thursday, January 8, 2015 & 10 & 14 & 12 & 12 & 48 & 44 & 7 & 6,857143 \\
\hline 4 & Friday, January 9, 2015 & 15 & 13 & 9 & 14 & 51 & 48 & 6 & 8,500000 \\
\hline 5 & Monday, January 12, 2015 & 13 & 16 & 11 & 13 & 53 & 52 & 7 & 7,571429 \\
\hline 6 & Tuesday, January 13, 2015 & 10 & 15 & 9 & 12 & 46 & 48 & 7 & 6,571429 \\
\hline 7 & Wednesday January 14, 2015 & 13 & 9 & 14 & 13 & 49 & 45 & 7 & 7,000000 \\
\hline 8 & Thursday, January 15, 2015 & 11 & 9 & 12 & 11 & 43 & 42 & 7 & 6,142857 \\
\hline 9 & Friday, January 16, 2015 & 10 & 9 & 10 & 11 & 40 & 38 & 6 & 6,666667 \\
\hline 10 & Monday, January 19, 2015 & 13 & 15 & 12 & 13 & 53 & 50 & 7 & 7,571429 \\
\hline 11 & Tuesday, January 20, 2015 & 12 & 14 & 12 & 10 & 48 & 47 & 7 & 6,857143 \\
\hline 12 & Wednesday January 21, 2015 & 13 & 9 & 11 & 12 & 45 & 42 & 7 & 6,428571 \\
\hline 13 & Thursday, January 22, 2015 & 15 & 11 & 12 & 14 & 52 & 50 & 7 & 7,428571 \\
\hline 14 & Friday, January 23, 2015 & 12 & 14 & 13 & 10 & 49 & 48 & 7 & 7,000000 \\
\hline 15 & Monday, January 26, 2015 & 14 & 12 & 13 & 14 & 53 & 50 & 7 & 7,571429 \\
\hline 16 & Tuesday, January 27, 2015 & 11 & 15 & 12 & 13 & 51 & 48 & 7 & 7,285714 \\
\hline 17 & Wednesday January 28, 2015 & 13 & 14 & 15 & 12 & 54 & 52 & 7 & 7,714286 \\
\hline 18 & Thursday, January 29, 2015 & 14 & 11 & 13 & 12 & 50 & 45 & 7 & 7,142857 \\
\hline 19 & Friday, January 20, 2015 & 13 & 15 & 14 & 11 & 53 & 48 & 6 & 8,833333 \\
\hline 20 & Monday, February 2, 2015 & 10 & 12 & 13 & 11 & 46 & 46 & 7 & 6,571429 \\
\hline 21 & Tuesday, February 3, 2015 & 14 & 15 & 12 & 10 & 51 & 48 & 7 & 7,285714 \\
\hline 22 & Wednesday, February 4, 2015 & 13 & 14 & 10 & 12 & 49 & 45 & 7 & 7,000000 \\
\hline 23 & Thursday, February 5, 2015 & 11 & 10 & 11 & 13 & 45 & 45 & 7 & 6,428571 \\
\hline 24 & Friday, February 6, 2015 & 10 & 13 & 14 & 12 & 49 & 45 & 6 & 8,166667 \\
\hline 25 & Monday, February 8, 2015 & 10 & 13 & 14 & 12 & 49 & 48 & 7 & 7,000000 \\
\hline & Count & 307 & 311 & 302 & 301 & 1221 & 1165 & 171 & 1,790000 \\
\hline
\end{tabular}

Referring to the table, then calculated the dimensions of the line that needs to be known, particularly with regard to solving the problem of research. The calculation of the value of cars lining up to wait for service (Lq), a car that is in the system (Ls), a car waiting in a line queue (Wq), while the car is in the system (Ws), chances are no cars in the system (Po ) and the ratio of the use of service facilities, and $P o=1-r(r)$. Furthermore, based on the values derived from it, and then calculated the adequacy of facilities available capacity and customer opportunities car owners can be immediately serviced without having to wait too long. Cars arriving for servicing during the 25 days of observation amounted to 1,221 units of the car. The car is finished servicing amounted to 1,165 units so that cars had to wait in line before being served amounted to 56 units. 
The proportion of the cars arriving can be served immediately (on time) reached an average of $95.52 \%$ and should wait first covering $4: 48 \%$. The cars arriving per day on average 48.84 units, a maximum of 55 units and a minimum of 40 units per day. The number of cars that can be directly serviced is an average of 46.6 units per day, with a maximum capacity of 52 units and a minimum of 42 units per day. In relation to that, the average car had to wait 2:24 units per day (48.84 - 46.6 units).

Table 3. Calculation of the service level value $(\mu)$ and serving customers probability on time

\begin{tabular}{|c|c|c|c|c|c|}
\hline Arrival of the car & $\begin{array}{l}\text { Number of } \\
\text { cars arriving } \\
\text { (units) }\end{array}$ & $\begin{array}{l}\text { Number of car } \\
\text { finished } \\
\text { services (units) }\end{array}$ & $\begin{array}{c}\text { The car } \\
\text { waiting for the } \\
\text { turn }\end{array}$ & $\begin{array}{c}\text { Percentage of } \\
\text { cars directly } \\
\text { served }\end{array}$ & $\begin{array}{c}\text { Percentage of } \\
\text { cars wait }\end{array}$ \\
\hline Tuesday, January 6, 2015 & 50 & 45 & 5 & 90.00 & 10.00 \\
\hline Wednesday, January 7, 2015 & 44 & 46 & -2 & 104.55 & -4.55 \\
\hline Thursday, January 8, 2015 & 48 & 44 & 4 & 91.67 & 8.33 \\
\hline Friday, January 9, 2015 & 51 & 48 & 3 & 94.12 & 5.88 \\
\hline Monday, January 12, 2015 & 53 & 52 & 1 & 98.11 & 1.89 \\
\hline Tuesday, January 13, 2015 & 46 & 48 & -2 & 104.35 & -4.35 \\
\hline Wednesday January 14, 2015 & 49 & 45 & 4 & 91.84 & 8.16 \\
\hline Thursday, January 15, 2015 & 43 & 42 & 1 & 97.67 & 2.33 \\
\hline Friday, January 16, 2015 & 40 & 38 & 2 & 95.00 & 5.00 \\
\hline Monday, January 19, 2015 & 53 & 50 & 3 & 94.34 & 5.64 \\
\hline Tuesday, January 20, 2015 & 48 & 47 & 1 & 97.92 & 2.08 \\
\hline Wednesday January 21, 2015 & 45 & 42 & 3 & 93.33 & 6.67 \\
\hline Thursday, January 22, 2015 & 52 & 50 & 2 & 96.15 & 3.85 \\
\hline Friday, January 23, 2015 & 49 & 48 & 1 & 97.96 & 2.04 \\
\hline Monday, January 26, 2015 & 53 & 50 & 3 & 94.34 & 5.66 \\
\hline Tuesday, January 27, 2015 & 51 & 48 & 3 & 94.12 & 5.88 \\
\hline Wednesday January 28, 2015 & 54 & 52 & 2 & 96.30 & 3.70 \\
\hline Thursday, January 29, 2015 & 50 & 45 & 5 & 90.00 & 10.00 \\
\hline Friday, January 20, 2015 & 53 & 48 & 5 & 90.57 & 9.43 \\
\hline Monday, February 2, 2015 & 46 & 46 & 0 & 100.00 & 0.00 \\
\hline Tuesday, February 3, 2015 & 51 & 48 & 3 & 94.12 & 5.88 \\
\hline Wednesday, February 4, 2015 & 49 & 45 & 4 & 91.84 & 8.16 \\
\hline Thursday, February 5, 2015 & 45 & 45 & 0 & 100.00 & 0.00 \\
\hline Friday, February 6, 2015 & 49 & 45 & 4 & 91.84 & 8.16 \\
\hline Monday, February 8, 2015 & 49 & 48 & 1 & 97.96 & 2.04 \\
\hline Count & 1,221 & 1,165 & 56 & 23.880 .745 & 1.119 .255 \\
\hline average & 48.84 & 46.6 & 2.24 & 9.552 .298 & 447.702 \\
\hline
\end{tabular}

*) The proportion of cars that are directly served and have to wait are calculated on their own

Source: Number of cars arriving and being serviced, based on Table 2.

Further, based on the data in Table 2 and Table 3 are calculated values related variable to then apply the equipment waiting line theory to determine the Lq, Ls, Wq, Ws and $r$ and Po of the 
system. Based on Table 4, a car arrived to ask for service per working day on average 48.84 units or rounded up to 49 units. Average per effective working hour is 7.1610 and rounded to 7 units per hour. The number of services per hour effective work is 6.8276 or rounded up to 7 units per hour so it can be served on all the available mechanical team reached 27.3104 units or rounded up to 27 units per hour. Facility usage rate $(\rho)$ is 0.2621 per team of mechanics or $1.048592(105 \%)$ to the level of the company. This means the company is very busy service facility. Mechanical does not get enough rest time.

Table 4. Calculation $\Lambda$ and $\mu$ with $\mathrm{M}=4$

\begin{tabular}{|c|c|c|c|c|c|}
\hline Arrival car & $\begin{array}{c}\text { Number of } \\
\text { cars arrived } \\
\text { (unit) }\end{array}$ & $\begin{array}{c}\text { effective } \\
\text { working per } \\
\text { hours }\end{array}$ & $\begin{array}{l}\text { Arrival car } \\
\text { per hour }(\Lambda)\end{array}$ & $\begin{array}{c}\text { Capable of } \\
\text { service per } \\
\text { hour }(\mu)\end{array}$ & $\begin{array}{c}\text { Level of } \\
\text { facility } \\
\text { usefulness (r) }\end{array}$ \\
\hline Tuesday, January 6, 2015 & 50 & 7 & 71.429 & 64.286 & 0.2778 \\
\hline Wednesday, January 7, 2015 & 44 & 7 & 62.857 & 65.714 & 0.2391 \\
\hline Thursday, January 8, 2015 & 48 & 7 & 68.571 & 62.857 & 0.2727 \\
\hline Friday, January 9, 2015 & 51 & 6 & 85.000 & 80.000 & 0.2656 \\
\hline Monday, January 12, 2015 & 53 & 7 & 75.714 & 74.286 & 0.2548 \\
\hline Tuesday, January 13, 2015 & 46 & 7 & 65.714 & 68.571 & 0.2396 \\
\hline Wednesday January 14, 2015 & 49 & 7 & 70.000 & 64.286 & 0.2722 \\
\hline Thursday, January 15, 2015 & 43 & 7 & 61.429 & 60.000 & 0.2560 \\
\hline Friday, January 16, 2015 & 40 & 6 & 66.667 & 63.333 & 0.2632 \\
\hline Monday, January 19, 2015 & 53 & 7 & 75.714 & 71.429 & 0.2650 \\
\hline Tuesday, January 20, 2015 & 48 & 7 & 68.571 & 67.143 & 0.2553 \\
\hline Wednesday January 21, 2015 & 45 & 7 & 64.286 & 60.000 & 0.2679 \\
\hline Thursday, January 22, 2015 & 52 & 7 & 74.286 & 71.429 & 0.2600 \\
\hline Friday, January 23, 2015 & 49 & 6 & 70.000 & 68.571 & 0.2552 \\
\hline Monday, January 26, 2015 & 53 & 7 & 75.714 & 71.429 & 0.2650 \\
\hline Tuesday, January 27, 2015 & 51 & 7 & 72.857 & 68.571 & 0.2656 \\
\hline Wednesday January 28, 2015 & 54 & 7 & 77.143 & 74.286 & 0.2596 \\
\hline Thursday, January 29, 2015 & 50 & 7 & 71.429 & 64.286 & 0.2778 \\
\hline Friday, January 20, 2015 & 53 & 6 & 88.333 & 80.000 & 0.2760 \\
\hline Monday, February 2, 2015 & 46 & 7 & 65.714 & 65.714 & 0.2500 \\
\hline Tuesday, February 3, 2015 & 51 & 7 & 72.857 & 68.571 & 0.2656 \\
\hline Wednesday, February 4, 2015 & 49 & 7 & 70.000 & 64.286 & 0.2722 \\
\hline Thursday, February 5, 2015 & 45 & 7 & 64.286 & 64.286 & 0.2500 \\
\hline Friday, February 6, 2015 & 49 & 6 & 81.667 & 75.000 & 0.2722 \\
\hline Monday, February 8, 2015 & 49 & 7 & 70.000 & 68.571 & 0.2552 \\
\hline Count & 1,221 & 171 & 1.790 .238 & 1.706 .905 & 65.537 \\
\hline average & 48.84 & 6.84 & 71.610 & 68.276 & 0.2621 \\
\hline
\end{tabular}

Value $\Lambda, \mu$ and $\rho$ are calculated itself with $\mathrm{M}=4$.

Source: research results (cars arriving and effective working hours).

Here will be presented the analysis of the calculation of cars queue waiting for service (Lq), the number of cars in the system (Ls), old cars waiting in line (Wq) and old cars in the system (Ws). 
Based on Table 5, the car that queued on average 0.0161 units per hour or 1 unit in 61 hours (= $1 /$ 0.0161). A car that is in the service facility, including those being served and who are waiting for service at an average of 1.0572 per hour, or about 7.231248 per weekday $(1.0572 \mathrm{x}$ 6.84 hours on average).

Therefore, there are opportunities, there are 4 cars being serviced and 3 other cars were waiting in the queue line. The average car is in the queue line is short, only 0.1296 minutes or about 7.78 seconds or rounded up to 8 seconds. However, the car is in the system around 8.9115 minutes 534.6911 seconds. The portion of the time spent in queue was about 1:46\% (7.78/534.6911 x 100) and used in receiving services activity reached 98.54\% (100 - 1:46\%). It is in excellent condition, because the car uses a relatively longer time to receive a service and only briefly be in a queue line. This result is consistent with the calculation of the amount of value Lq and Ls.

Table 5. Calculation Lq, Ls, Wq and Ws with $\mathrm{M}=4$

\begin{tabular}{|c|c|c|c|c|c|c|c|c|}
\hline No. & $\begin{array}{c}\Lambda \text { (units / } \\
\text { hour) }\end{array}$ & $\begin{array}{l}\mu \text { (units / } \\
\text { hour) }\end{array}$ & $\rho$ & Po & $\begin{array}{l}\text { Lq (units } \\
\text { / hour) }\end{array}$ & $\begin{array}{l}\text { Ls (units / } \\
\text { hour) }\end{array}$ & $\begin{array}{c}\mathrm{Wq} \\
\text { (minutes) }\end{array}$ & $\begin{array}{c}\mathrm{Ws} \\
\text { (minutes) }\end{array}$ \\
\hline 1 & 71.429 & 64.286 & 0.2778 & 0.7222 & 0.0111 & 11.222 & 0.0933 & 94.265 \\
\hline 2 & 62.857 & 65.714 & 0.2391 & 0.7609 & 0.0056 & 0.9621 & 0.0530 & 91.837 \\
\hline 3 & 68.571 & 62.857 & 0.2727 & 0.7273 & 0.0102 & 11.011 & 0.0893 & 96.346 \\
\hline 4 & 85.000 & 80.000 & 0.2656 & 0.7344 & 0.0090 & 10.715 & 0.0635 & 75.635 \\
\hline 5 & 75.714 & 74.286 & 0.2548 & 0.7452 & 0.0074 & 10.267 & 0.0586 & 81.361 \\
\hline 6 & 65.714 & 68.571 & 0.2396 & 0.7604 & 0.0056 & 0.9639 & 0.0511 & 88.008 \\
\hline 7 & 70.000 & 64.286 & 0.2722 & 0.7278 & 0.1010 & 10.990 & 0.8657 & 94.200 \\
\hline 8 & 61.429 & 60.000 & 0.2560 & 0.7440 & 0.0076 & 10.314 & 0.0742 & 100.741 \\
\hline 9 & 66.667 & 63.333 & 0.2632 & 0.7368 & 0.0086 & 10.613 & 0.0774 & 95.517 \\
\hline 10 & 75.714 & 71.429 & 0.2650 & 0.7350 & 0.0089 & 10.689 & 0.0705 & 84.705 \\
\hline 11 & 68.571 & 67.143 & 0.2553 & 0.7447 & 0.0075 & 10.288 & 0.0656 & 90.020 \\
\hline 12 & 64.286 & 60.000 & 0.2679 & 0.7321 & 0.0094 & 10.808 & 0.0877 & 100.875 \\
\hline 13 & 74.286 & 71.429 & 0.2600 & 0.7400 & 0.0082 & 10.482 & 0.0662 & 84.662 \\
\hline 14 & 70.000 & 68.571 & 0.2552 & 0.7448 & 0.0075 & 10.283 & 0.0643 & 88.140 \\
\hline 15 & 75.714 & 71.429 & 0.2650 & 0.7350 & 0.0089 & 10.689 & 0.0705 & 84.705 \\
\hline 16 & 72.857 & 68.571 & 0.2656 & 0.7344 & 0.0090 & 10.715 & 0.0741 & 88.241 \\
\hline 17 & 77.143 & 74.286 & 0.2596 & 0.7404 & 0.0081 & 10.466 & 0.0630 & 81.402 \\
\hline 18 & 71.429 & 64.286 & 0.2778 & 0.7222 & 0.0111 & 11.222 & 0.0932 & 94.265 \\
\hline 19 & 88.333 & 80.000 & 0.2760 & 0.7240 & 0.1080 & 11.150 & 0.7336 & 75.736 \\
\hline 20 & 65.714 & 65.714 & 0.2500 & 0.7500 & 0.0068 & 10.068 & 0.0621 & 91.925 \\
\hline 21 & 72.857 & 68.571 & 0.2656 & 0.7344 & 0.0090 & 10.715 & 0.0741 & 88.241 \\
\hline 22 & 70.000 & 64.286 & 0.2722 & 0.7278 & 0.0101 & 10.990 & 0.0866 & 94.200 \\
\hline 23 & 64.286 & 64.286 & 0.2500 & 0.7500 & 0.0068 & 10.068 & 0.0635 & 93.968 \\
\hline 24 & 81.667 & 75.000 & 0.2722 & 0.7278 & 0.0101 & 10.990 & 0.0742 & 80.743 \\
\hline 25 & 70.000 & 68.571 & 0.2552 & 0.7448 & 0.0075 & 10.283 & 0.0643 & 88.140 \\
\hline Count & 1.790 .238 & 1.706 .905 & 65.537 & 184.463 & 0.4030 & 264.298 & 32.398 & 2.227 .880 \\
\hline average & 71.610 & 68.276 & 0.2621 & 0.7379 & 0.0161 & 10.572 & 0.1296 & 89.115 \\
\hline
\end{tabular}




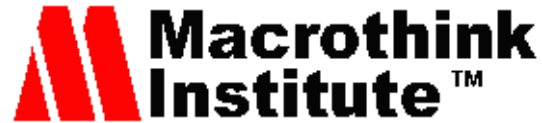

World Journal of Business and Management

ISSN 2377-4622

2017, Vol. 3, No. 1

Based on the table 5, then the chances of service facilities is empty, do not give the service is 0.7379 or $73.79 \%$ for $M=4$. Therefore, on per channel services (per team mechanic) there is a blank chance by $18: 45 \%(1 / 4 \times 73.79$ percent $)$. With that data, it can be seen that the service facility to PT. XYZ is very busy. Only there is a chance $18: 45 \%$ to empty or not work serving the customers, so that the two key issues in this study, namely: (a) Is the facility capacity available services can be used to answer the demand is there, and (b) Whether the customer gets the service immediately after arriving and did not have to wait long before getting the services required. Both the research problem was answered and solved.

Service capacity in XYZ assessed as adequate. Opportunities of system that do not provide service (empty) at each mechanical team equal to $18.45 \%$ and car queue per hour is relatively small, only 1 unit in 61 hours (equivalent to 9 effective working days). Thus, there are no compelling reasons to increase system capacity. The car that queued service 56 units within 25 working days, or 2:24 units per working day, or about 9 units within 4 working days. Analysis also showed that the car does not have to wait long to get their turn for service. Probabilistically, only takes about 8 seconds waiting service. Thus, both the subject matter of research has been answered with the analysis presented above.

\section{Conclusion and Discussion}

PT. XYZ is not required to increase the capacity of its services in an effort to satisfy customers. The results of the analysis prove that the cars arriving per hour as much as 7.1610 units. 6.8276 hourly service capacities for 4 units and total capacity mechanical team are 27.3104 units. Therefore, the total capacity is adequate; there is a tendency to be able to serve the maintenance of all the cars that arrived at without having to wait a long time in advance. In fact, through the application of queuing theory equipment, customers only waited about 8 seconds before it is served. And will be in the system around 8.9115 minutes. The proportion of the use of time for service are quite significant when compared with the time to line up, reaching $98.54 \%$. The use of time to line up just 1:46\%.

If a customer states that the average time spent in the car maintenance activity is 5 hours (Ws), including waiting time $(\mathrm{Wq})$ and undergo servicing activities. By using the proportion of time in question, there will be approximately 0.073 hours to wait (4:38 minutes, or rounded up to 5 minutes). Time used for servicing approximately 4 hours 55 minutes. Thus, for relevance of realities facing in car maintenance activity in PT. XYZ, can utilize the proportion of service time and waiting time as described above. It can be concluded that at the present time PT. XYZ yet have a compelling reason to increase the capacity of the service. During this time with 4 mechanical teams deemed to have been sufficient to provide satisfactory services to the customers (owners of Suzuki cars) because customers do not need to wait a long time to get a turn to service and service facilities in PT. XYZ.

\section{References}

Chowdhury, M. S. R., Rahman, M. T., \& Kabir, M. R. (2013). Solving of waiting lines models in the bank using queuing theory model the practice case: Islami bank bangladesh limited, 


\section{Macrothink}

World Journal of Business and Management

ISSN 2377-4622

2017, Vol. 3, No. 1

chawk bazar branch, chittagong. IOSR Journal of Business And Management, 10, 22-29. https://doi.org/10.9790/487X-1012229

Haming, Murdifin., Ramlawati, Suryanti, \& Imad. (2017). Operations Research: Optimal Decision Making Techniques. Publishers Earth Literacy, Jakarta.

Heizer, J., Barry, R., \& Chuck, M. (2017). Operations Management: Sustainability and Supply ChainManagement (12th ed.). Global Edition. Pearson Education Limited, Boston Colombus Indianapolis New York.

Jacobs, F. R., \& Chase, R. B. (2011). Operations \& Supply Chain Management (13rd ed.). McGraw Hill Irwin, Boston Burr Ridge.

Osahenvemwen, O. A., \& Odiase, O. F. (2016). Effective Utilization of Mobile Call Center Using Queuing Models. International Journal of Engineering and Technology, 8(2), 107-111. https://doi.org/10.7763/IJET.2016.V8.867

Oyatoye, E. O., Adebiyi, S. O., Okoye, J. C., \& Amole, B. B. (2011). Application of Queueing theory to port congestion problem in Nigeria. European Journal of Business and Management, 3(8), 24-36.

Taha, H. A. (2003). Operations Research: An Introduction (7th ed.). Publisher Pearson Education International, Upper Saddle River, New Jersey.

\section{Copyright Disclaimer}

Copyright for this article is retained by the author(s), with first publication rights granted to the journal.

This is an open-access article distributed under the terms and conditions of the Creative Commons Attribution license (http://creativecommons.org/licenses/by/3.0/). 